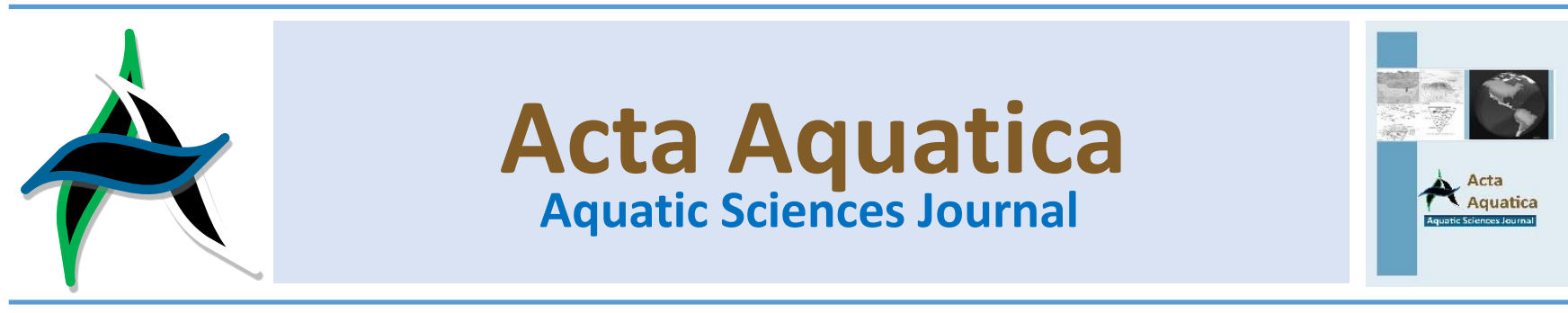

\title{
The occurrence of the Atlantic species Pisodonophis semicinctus (Osteichthyes: Ophichthidae) in the Gulf of Antalya, Turkey
}

\author{
Mehmet Gökoğlu $^{\text {a, } *}$, Erkan Biçer ${ }^{b}$, Kemal Gökoğlu ${ }^{c}$, Jale Korun ${ }^{a}$ and Serkan Teker ${ }^{a}$ \\ ${ }^{a}$ Faculty of Fisheries, Akdeniz University, Turkey \\ ${ }^{\mathrm{b}}$ Antalya Directorate of Provincial Agricultural and Forestry \\ cAkdeniz Üniversity
}

\begin{abstract}
Fishermen caught a different eel species at night with hook on July 7, 2019 (36 48'59.21"N: 30³8'23.44"E). This fish has not been seen before in the Gulf of Antalya. This fish was identified as Pisodonophis semicinctus (Richardson, 1848). With the identification of this fish, a new species was added to the fish fauna of the Gulf of Antalya. In the present paper, we reported $P$. semicinctus for the first time from the Gulf of Antalya, Turkey (North-Eastern Mediterranean), for the third time from marine waters of Turkey.
\end{abstract}

Keywords: Occurence; Pisodonophis semicinctus; the Gulf of Antalya

\section{Introduction}

The Mediterranean Sea was connected to both the Atlantic and the Indian Ocean with the opening of the Suez Canal in 1869. Therefore, there are migrations from both oceans to the Mediterranean Sea. Turkey's Mediterranean coast is located in the eastern Mediterranean ecosystem called the Levantine Sea. The Levantine Sea, which is the eastern part of the Mediterranean Sea, is under the influence of immigration from Indo-Pacific through the Suez Canal (Zenetos 2017). Many lessepsian organisms have been recorded by researchers on the coasts of Turkey (Cinar et al., 2011).

Originally built as shallow and narrow, the Suez Canal was expanded and deepened over the years. These changes in the channel triggered migration from the Red Sea to the Mediterranean Sea. Zenetos (2017) investigated the effects of deepening and expanding the Suez Canal. It was reported that 19 alien species were recorded within two years after the canal expansion completed in the study.

In addition to Indo-pacific migrations through the Suez Canal in the Mediterranean, there are also occasional migrations from the Atlantic Ocean. Fishes are among the most migrating organisms. Pisodonophis semicinctus (Richardson, 1848), a species of eel, is one of the species that migrate from the Atlantic to the Mediterranean Sea (Ambrogi, 2002).

\footnotetext{
* Corresponding author: Faculty of Fisheries, Akdeniz University, 07058. Antalya, Turkey. Tel: +905358554167
}

e-mail:gokoglu@akdeniz.edu.tr

doi: http://doi.org/10.29103/aa.v7i1.2091
Eight species of eel belonging to the Ophichthidae family are reported in the Mediterranean Sea. One of these fish is $P$. semicinctus (Bodilis et al. 2012). The species which its main habitat is the East Atlantic coast is very rare in the Mediterranean Sea (Ragonese and Giusto, 2000; Ambrogi 2002).

The Gulf of Antalya is located in the eastern Mediterranean ecosystem and is therefore, one of the places where exotic species migrants are mostly seen (Teker and Gökoğlu 2017). Fishermen caught a alien eel species on their fishing line during the night fishing in the Gulf of Antalya caught. The purpose of this study is to identify this species that were not seen in the Gulf of Antalya and to add them to the fauna of Antalya Bay.

\section{Materials and methods}

During the 7 July 2019 night fishing operations, the fishermen caught a different kind of eel with a fishing line at the depths of $40 \mathrm{~m}$ in coordinates $36^{\circ} 48^{\prime} 59.21$ "N: $30^{\circ} 38^{\prime} 23.44^{\prime \prime} \mathrm{E}$ of the gulf of Antalya. The fishermen brought this eel, which they thought was a poisonous species, to humans.

Species determination of this eel was carried out according to Bauchot (1986) and Bilecenoglu et al. (2009). The specimen was fixed in $4 \%$ formalin and it is preserved in the City Museum of Kepez Municipality (Antalya).

\section{Result and discussion}

One specimen of saddled snake eel $(86 \mathrm{~cm}$ in total length and $570 \mathrm{~g}$. in weight) was captured by a hook at a depth of $40 \mathrm{~m}$ in the Gulf of Antalya in 7 July 2019 at night (Figure 1 
and Figure 2). Its body is elongated and almost cylindrical. Anterior nostril tubular is located at the front sides of the snout, projecting downwards. Posterior nostril as small openings on upper lip is covered by a flap. Dorsal and anal fins developed, but not confluent. Caudal fin is absent, tip of tail is hard and pointed.

Predorsal length is $8.2 \mathrm{~cm}$, preanal length is $39.1 \mathrm{~cm}$, head length is $9.5 \mathrm{~cm}$ and body depth is $4 \mathrm{~cm}$, all as a percentage of total length. Eye diameter is $6 \mathrm{~mm}$, snout is length $16 \mathrm{~mm}$, all as a percentage of head length. Body color is yellowish anteriorly and browns at rest, with saddle-like dark patches ( 2 on the head and 16 over the body). There are several small dark spots on the head, except for the nape. All fins are black edged of the fish.

We identified this fish as saddled snake eel ( $P$. semicinctus). Our findings were the same as those of other investigators (Bauchot, 1986; Ragonese \& Giusto, 2000; Bilecenoğlu et al., 2009; Yağlıoğlu \& Ayas, 2016). P. semicinctus usually burrows on sandy and muddy bottoms in coastal waters at depths from 10 to $30 \mathrm{~m}$ (Bauchot, 1986) where it is often caught by beach fishing nets and hook (Bodilis et al., 2012).
The specimen was fixed in $4 \%$ formalin and it is preserved in the City Museum of Kepez Municipality. The Atlantic-originated snake eel, Pisodonophis semicinctus (Actinopteri: Anguilliformes: Ophichthidae), was recorded for the first time in the Mediterranean Sea in 1957 from Cherchell (Algeria) (Dieuziede \& Roland, 1958). After this recording, fish were reported from 12 different regions of the Mediterranean (Yağlıoğlu \& Ayas, 2016). In the present paper, we reported $P$. semicinctus for the first time from the Gulf of Antalya, Turkey (North-Eastern Mediterranean), for the third time from the marine waters of Turkey.

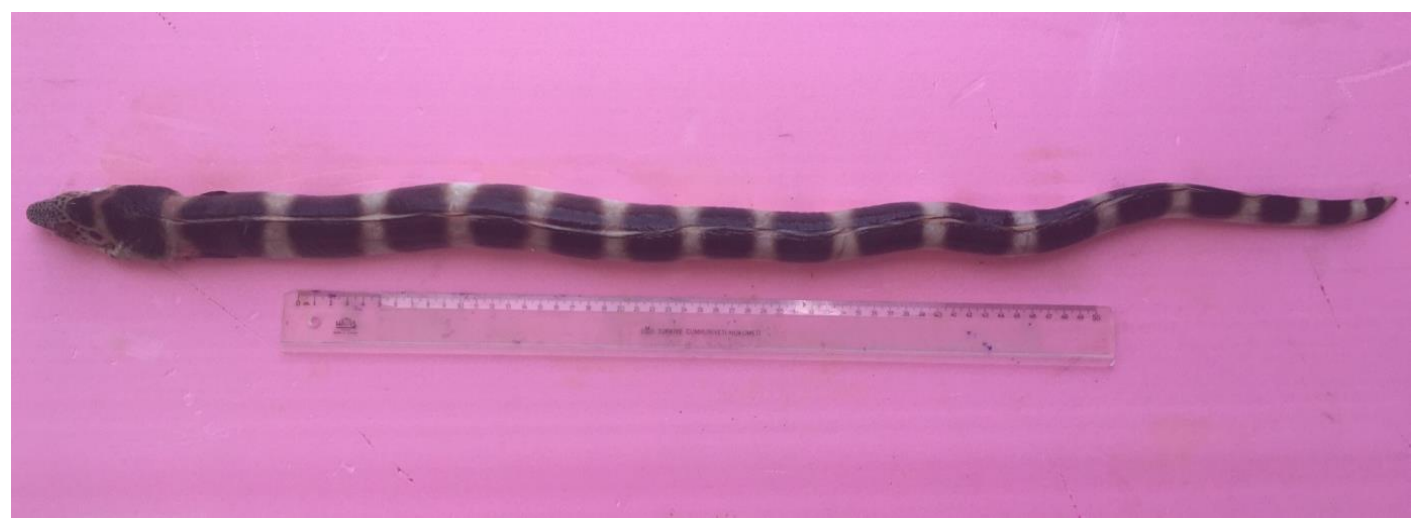

Figure 1. Pisodonophis semicinctus caught in the Gulf of Antalya

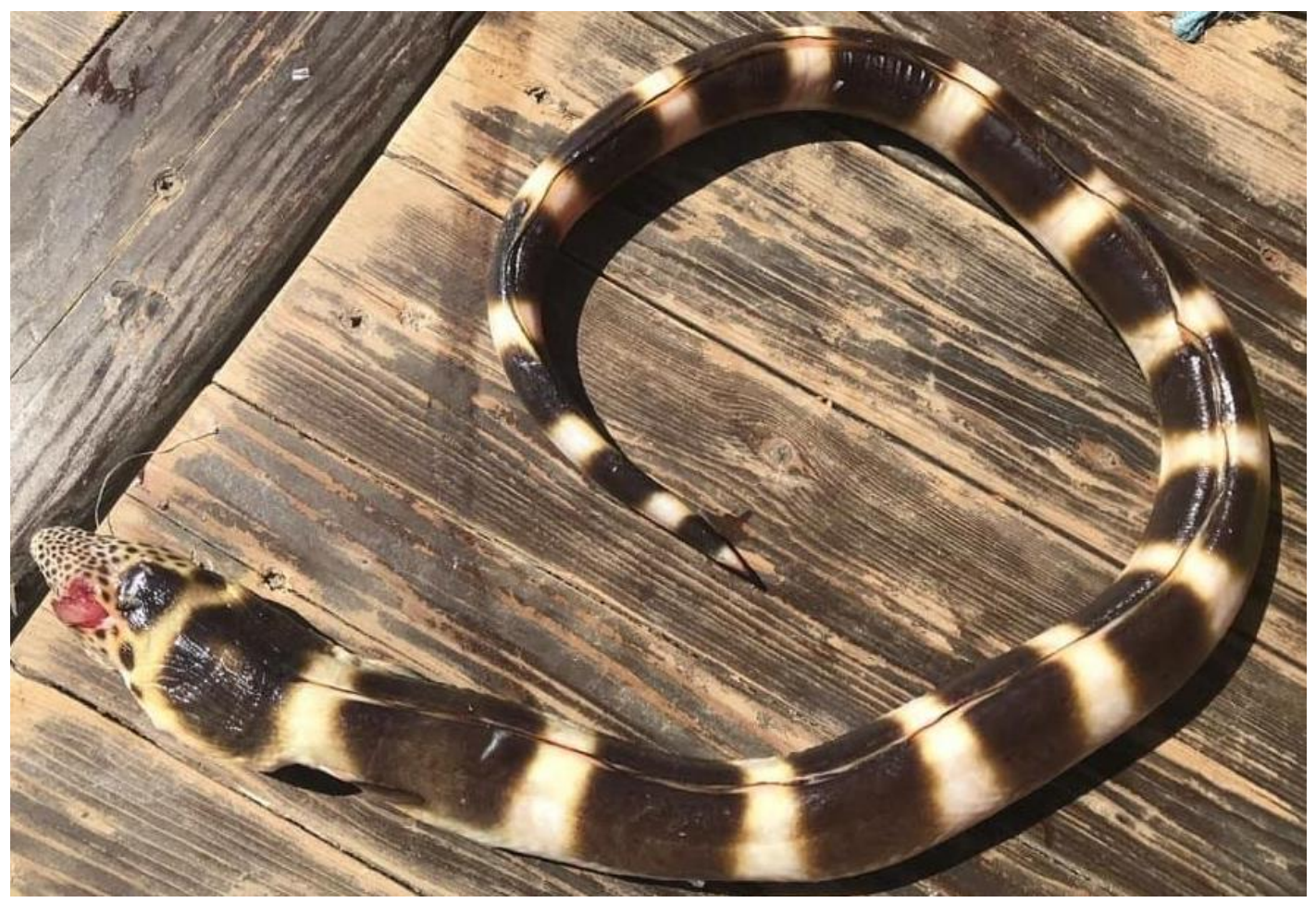

Figure 2. Pisodonophis semicinctus caught in the Gulf of Antalya 


\section{Bibliography}

Ambrogi, A. O., 2002. Current Status of Aquatic Introductions in Italy. P 311-325. Editor: Leppäkoski, E., Gollasch, S., Olenin, S. Invasive Aquatic Species of Europe. Distribution, Impacts and Management.

Bauchot, M. L., 1986. Ophichthidae. In: Fishes of the NorthEasternAtlantic and the Mediterranean. P. J. P. Whitehead, M. L.Bauchot, J. C. Hureau, J. Nielson, E. Tortonese (Eds), UNESCO, Paris, pp. 577-585.

Bilecenoglu, M.; Kaya, M.; Eryigit, A., 2009: New data on the occurrence of two alien fishes, Pisodonophis semicintus and Pomadasys stridens, from the Eastern Mediterranean Sea. Medit. Mar. Sci. 10: 151-155.

Bodilis, P., Chemine'e, A., Miniconi, R., Arceo, H., Francour, P., 2012. Occurrence of the Atlantic species, Pisodonophis semicinctus (Osteichthyes: Ophichthidae), along the Mediterranean coast. J. Appl. Ichthyol. 28, 652-654.

Çınar, M. E., Bilecenoglu, M., Ozturk, B., Katagan, T., Yokes, M., Aysel, V., Daglı, E., Acık, S., Ozcan, T. Erdogan, H., 2011. An updated review of alien species on the coasts of Turkey. Mediterranean Marine Science, 12(2): 257-315.

Dieuziede, R., Roland, J., 1958. Deuxieme complement au catalogue des poissons des cotes algeriennes. Bull. travaux publies par la station d'aquaculture et de peche de. Castiglione 9: 103-132.

Ragonese, S., Giusto, G. B., 2000. On a saddled snake eel Pisodonophis semicinctus (Osteichthyes: Ophichthidae) trawled in the Strait of Sicily (Mediterranean Sea). J. Mar. Biol. Ass. U.K. 80: 951-952.

Teker, S., Gökoğlu, M., 2017. Detection of members of Tetraodontidae and Ostraciidae Family in the Gulf of Antalya. Internation Symposium on Pufferfish, 13-14 October 2017, Bodrum, Turkey

Yağlıoğlu, D., Ayas, D., 2016. New occurrence data of four alien fishes (Pisodonophis semicinctus, Pterois miles, Scarus ghobban and Parupeneus forsskali) from the North Eastern Mediterranean (Yeşilovacık Bay, Turkey). Biharean Biologist, 10(2): 150-152.

Zenetos, A., 2017. Progress in Mediterranean bioinvasions two years after the Suez Canal enlargement. Acta Adriata, 58(2): 347-358. 